\title{
6. MICROSCOPICAL SURVEY OF ORGANIC MATTER FROM DSDP SITES 361, 362, AND 364
}

\author{
J.F. Raynaud and P. Robert, Elf-Aquitaine Research Center, 31360 Boussens, France
}

\section{METHODOLOGY}

Eight samples from DSDP Sites 361,362 , and 364 were studied by both petrographical and palynological techniques, using two kinds of preparations:

1) For petrographic studies, thin rock sections were examined in both reflected and transmitted light with one horizontal and one vertical specimen for each sample. This was to determine the composition of the organic material and the extent of its thermal alteration by measurement of the reflectance (in oil) of coaly particles.

2) Palynological slides were examined in order to determine the composition of organic material and the Thermal Alteration Index (TAI) of microfossils. Two slides were studied for each sample. The slides were prepared as follows: slide $1-\mathrm{HCl}, \mathrm{HF}, \mathrm{HCl}$, separation with Zinc Bromide; slide 2- $\mathrm{HCl}, \mathrm{HF}$, $\mathrm{HCl}, \mathrm{HNO} 3$ (50\%, 15 minutes), separation with Bromoform + Alcohol.

\section{SITE 361}

Four samples were studied.

\section{Sample 28-6, 33-38 cm: Lower Aptian Shale}

Petrography (Plates 1, 2)-Silty shale with interbedded lenses of organic matter and frequent pyrite globules. The organic matter consists of coaly particles and bituminous veinlets (Plate 1, Figures la, 1b) and particles.

The coal fragments are varied, with vitrinite (telinite, phlobaphinite), fusinite, and sporinite. Algae are abundant and show an intense fluorescence in UV light (Plate 1, Figure 2). Other fluorescent macerals (mainly alginite), are abundant and associated with fusinites and bitumen (both not fluorescent).

The reflectance measurements give a scattered histogram with vitrinite and bitumen, the latter having a mean value of $0.50 \%$.

Palynology-Slide 2 (Plate 3, Figure 3): Brown flakes of amorphous sapropelic matter; less than 5\% ligneous debris (fusinite); spores, pollen grains, and marine dinoflagellates.

Slide 1: Organic constituents similar to Slide 2, plus pyrite. $\mathrm{TAI}=2.5$. Corresponds to about $0.5 \%$ reflectance.

\section{Sample 32-5, 34-38 cm: Lower Aptian Shale}

Petrography-Silty shale with thin organic laminae and abundant dispersed particles of fusinite, sporinite and vitrinite.

Some patches of algal material or rarely figurated cellular algae (flat, spherical) are moderately fluorescent in UV light, though less than in the previous sample $(28-6,33-38 \mathrm{~cm})$.

Some bitumen veinlets are present; they are not fluorescent and have a lower reflectance than vitrinite $(0.5 \%)$.

The reflectance diagram of vitrinite constituents, spread widely between $0.6 \%$ and $1.3 \%$, has an average value of $0.8 \%-1 \%$.

Palynology-Mixed palynofacies (Figure 2): light brown flakes of amorphous sapropelic matter (30\%, slide $2 ; 45 \%$, slide 1); brown ligneous debris (5\%); black ligneous debris of fusinite $(50 \%)$. Spores, pollen grains, and marine dinoflagellates are present.

TAI of $3^{-}$should correspond to a reflectance of about $0.70 \%$.

\section{Sample 40-4, 101-104 cm: Lower Aptian Shale}

Palynology-Mixed palynofacies. Slide 2:60\% brown or red-brown flakes of amorphous sapropelic matter; black debris (fusinite) $40 \%$; rare brown ligneous debris. Slide 1: idem but with $30 \%$ black microdebris with pyrite and darker flakes. Spores, pollen grains. TAI of $3^{-}$should correspond to a reflectance of about $0.70 \%$.

\section{Sample 47-1, 96-101 cm: Lower Aptian Shale}

Petrography-Shaly-silty rock that is locally siliceous within a microcrystalline structure interbedded with thin organic laminae. Abundant pyrite globules.

Very rich in coaly reflecting particles such as vitrinite, telovitrinite, fusinite, sporinite. Some patches of alginite and unicellular flat or circular algae with a pale yellow fluorescence.

The mean value of vitrinite reflectance is in the neighborhood of $1 \%$.

Palynology-Mixed palynofacies. Slide 2 (Plate 2, Figure 1): $30 \%$ of amorphous sapropelic matter, $60 \%$ ligneous black debris (fusinite), and $10 \%$ brown ligneous debris. Slide 1 shows the same components but with fewer terrestrial ligneous debris (30\%). Spores, pollen grains, and marine dinoflagellates. TAI of 3 should correspond to a reflectance of about $0.80 \%$.

\section{Conclusions}

On the whole, these samples are rich in organic matter (Table 1). Section 28-6 shows a typical sapropelic facies, whereas Sections 32-5, 40-4, and 47-1 show a mixed facies with sapropelic matter and terrestrial ligneous debris. Algal material is frequent. The histograms of reflectance (in oil) testify to a moderate thermal diagenesis in sections $32-5$ and $47-1$ with an average value reaching $1 \%$ in the latter. The TAI evaluated on spores suggests slightly lower values $(0.70 \%)$. Section $28-6$ does not provide an adequate 
TABLE 1

Organic Content and Diagenesis

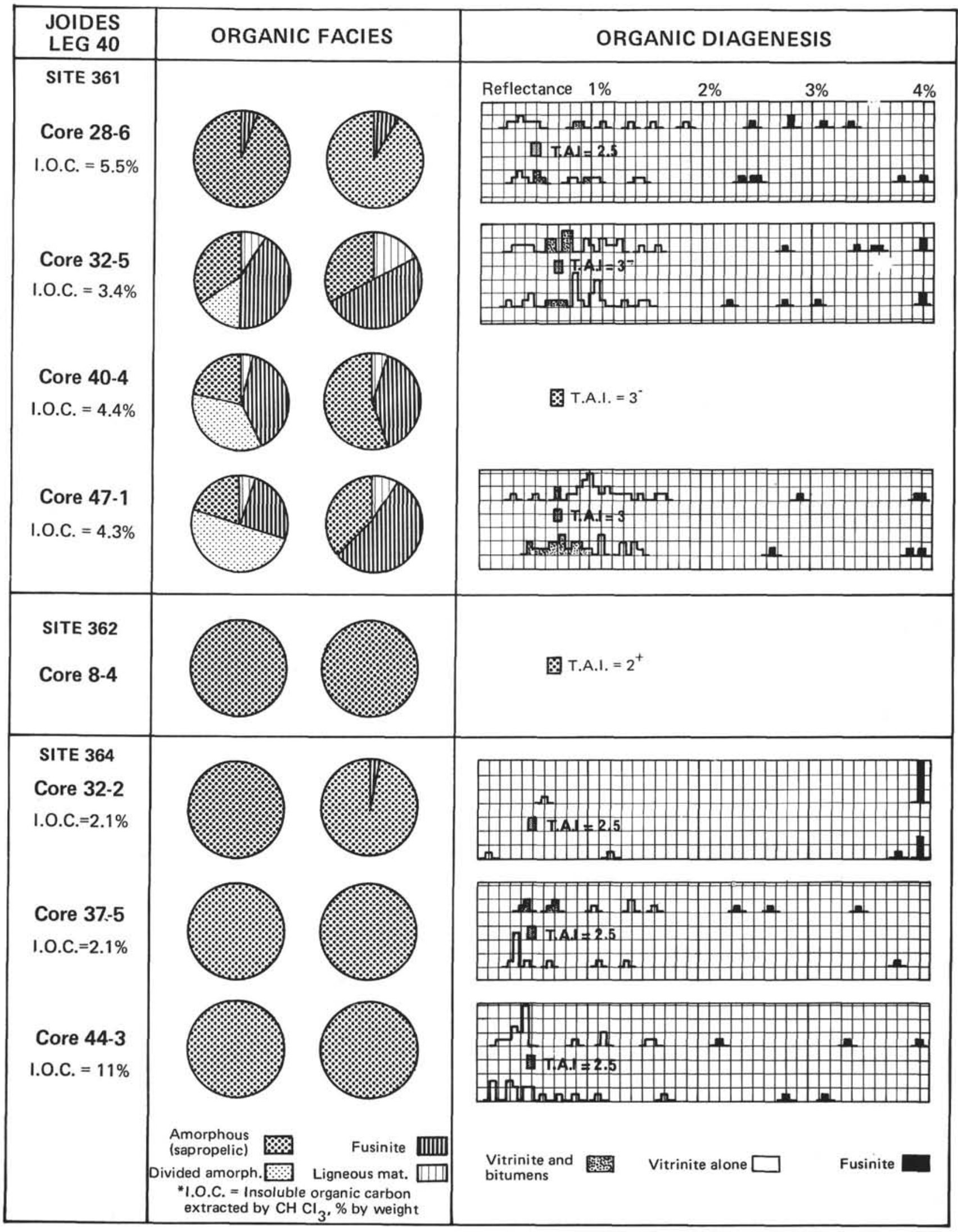


histogram because of a lack of coaly particles, although certain values are fairly low, in accordance with the TAI ( 2.5 reflectance $0.5 \%)$. What does tie in with these results is the strong fluorescence of alginite and fluorinite in Section 28-6 and weaker fluorescence in Section 32-5 and 47-1.

In all samples, bitumen particles and veinlets, with a lower reflectance than vitrinite, show up as remnant traces of migrating oil.

\section{SITE 362}

\section{Sample 8-4, 41-45 cm}

Palynology-100\% small flakes of light brown amorphous matter. Presence of a few modern pollen grains (Graminae, Chenopodiaceae, Compositae) and of Classopollis and some dinoflagellates. Thermal Alteration Index $=2.5$.

This sample is obviously not representative, and may have been polluted by drilling mud.

\section{SITE 364}

\section{Sample 32-2, 127-130 cm: Albian Limestone}

Petrography-Fairly silty cryptocrystalline marly limestone. Some thin laminae of brown organic matter; this material has no reflectance; it is rich in pyrite spherules. A few spores and algae that are only faintly fluorescent in UV light are dispersed in the ground mass. No reflectance data are available.

Palynology-Heterogeneous amorphous matter; pyrite in slide 1. Spores, pollen grains, and dinoflagellates of upper Albian age. TAI $2.5 \%$ should correspond to a reflectance of about $0.5 \%$.

\section{Sample 37-5, 128-131 cm Albian Marly Limestone}

Petrography-Marly shale with carbonated patches of epigenized foraminifers and fine dolomite rhombs. Abundant organic matter, in anastomozed beds, with much pyrite. Pyrite also abundant in foraminifers and isolated spherules.
In UV light, the organic matter shows, in mass, a pale yellow-brown fluorescence. Some brownish spores and very rare algae are present.

Reflecting organic particles: huminite, fusinite, and resinite are present though not abundant. Huminite gives a pattern of low-rank reflectance $(0.35 \%)$. Some small bituminous droplets and veinlets testify to oil migration.

Palynology-Amorphous matter exists in a mass of microparticles as in Section 32-2. Presence of very rare particles of fusinite and of small dark brown spheres. TAI of 2.5 should correspond to a reflectance of $0.50 \%$.

\section{Section-Albian Black Shale: 44-3}

Petrography-A facies rich in organic matter: 1) The rock is quartzo-phyllitic, cryptocrystalline with detrital silt and a great deal of dispersed framboidal pyrite. It contains a large amount of organic laminae, which represent about $40 \%$ of the whole (Plate 2, Figure 1). (2) This matter consists of resinite, huminite together with micrinite. (3) The UV fluorescence is medium pale, diffused throughout the rock. (4) The mean reflectance of huminitic material is in the range of $0.45 \%$.

Palynology-100\% compact flakes of amorphous matter (probably sapropelic) which shows up dark on slide 1 (pyrite) and yellow and reddish on slide 2 (Plate 3 , Figures 4,5 ). Very few ligneous particles: fusinite. TAI of 2.5, should correspond to a reflectance of $0.50 \%$.

\section{Conclusions}

The three samples from the Albian of Site 364 are characterized by sapropelic matter of probable algal origin. This is particularly evident in Section 32-2. In all three samples, there are only a few ligneous particles with any definite shape such as fusinite.

The extent of organic diagenesis is low, with a reflectance of about $0.45 \%$. This is confirmed by the Thermal Alteration Index of the microfossils, with a value of 2.5 . 
PLATE 1
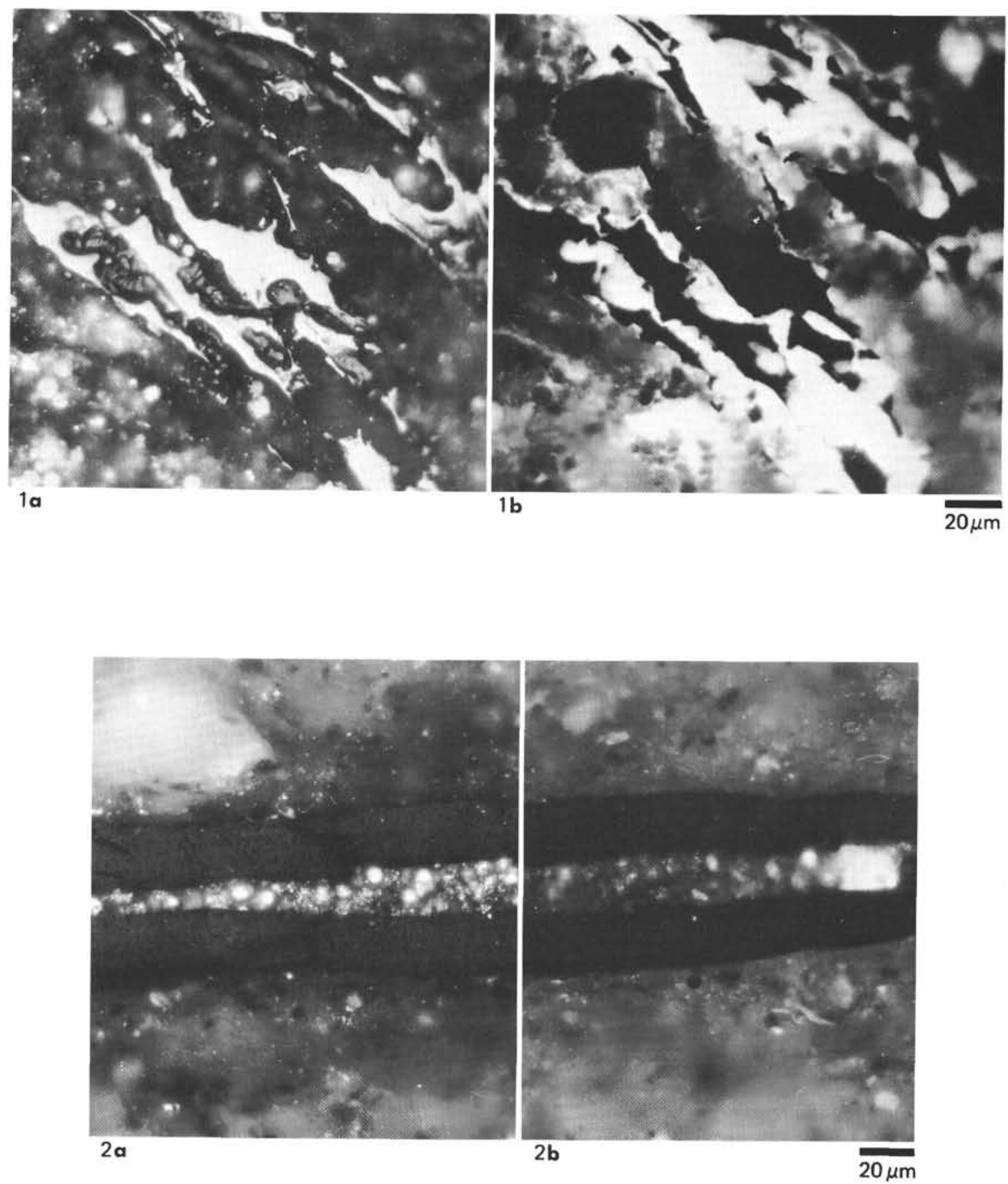

Figure 1 Section 361-28-6-(a) reflected light white = fusinite; (b) UV light (fluorescence), yellow (white here) organic matter within fusinite. $\times 400$.

Figure 2 Section 361-28-6-Bitumen veinlet-(a) reflected light; (b) UV light (flurescence) with yellow algal matter (white here). 


\section{PLATE 2}
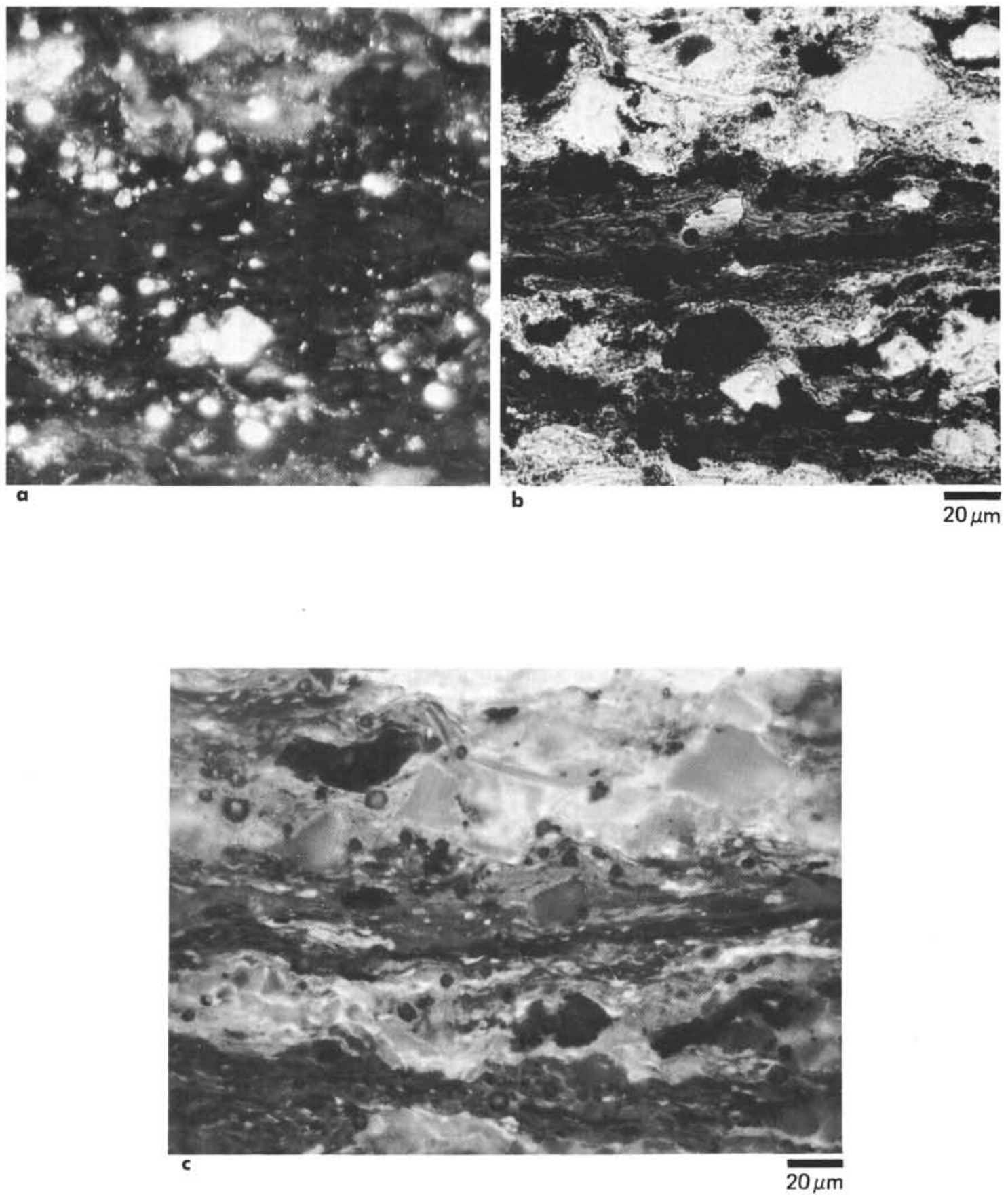

Figure $1 \quad$ Section $364-44-3$ - (a) reflected light: the white portion = pyrite, the gray area in the middle of the field = organic matter, huminite, resinite; (b) transmitted light : black = pyrite + reflecting organic matter; white and gray $=$ reddish translucent organic matter in the groundmass; (c) UV light (fluorescence): gray = reddish translucent organic matter in the groundmass. All figures $\times 400$. 


\section{PLATE 3}

All figures $\times 260$

Figure $1 \quad$ Section 361-47-1-Mixed palynofacies: ligneous particles, fusinite, spores, and pollen grains with flakes of amorphous organic matter.

Figure 2 Section 361-32-5-idem-interferential contrast.

Figure 3 Section 361-28-6-Amorphous organic matter with a few ligneous and coaly particles, spores, and pollen grains.

Figure 4 Section 364-44-3-Solid flake of sapropelic organic matter.

Figure 5 Section 364-44-3-Flake of sapropelic organic matter. 
PLATE 3
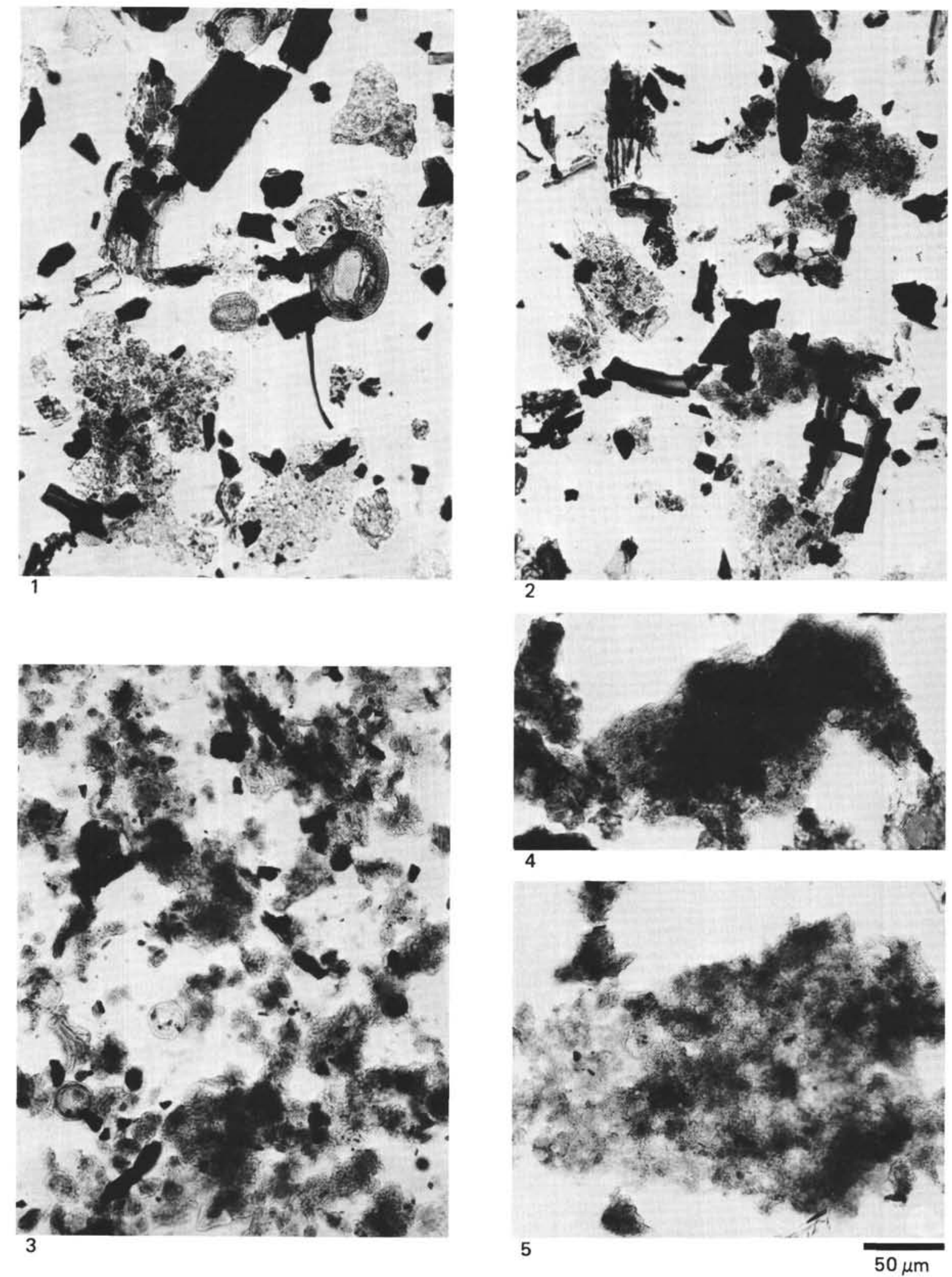